\title{
Stres rodzicielski matek dzieci z autyzmem
}

ABSTRACT: Anna Banasiak, Stres rodzicielski matek dzieci z autyzmem [Parental stress observed among mothers of autistic children]. Interdyscyplinarne Konteksty Pedagogiki Specjalnej, nr 19, Poznań 2017. Pp. 115-132. Adam Mickiewicz University Press. ISSN 2300-391X

The aim of the research presented in this article was to determine the level of parental stress among mothers of autistic children. Thirty-nine mothers of autistic children, forty mothers of children with Down syndrome took part in the research as well as forty mothers of children with regular development. We used the Questionnaire on Resources and Stress (QRS, designed by J. Holroyd) to assess parental stress among families of developmentally delayed or children with intellectual disability. The results of the research indicate that comparing to mothers of children with Down syndrome and mothers of children with regular development mothers of autistic children are the ones who experience the higher level of parental stress. Potential sources of coping strategies among mothers of children that suffer autism are associated with relatively low stress as a result of disharmony in the family, personal issues, child's health situation and financial problems

KEY WORDS: autism, parental stress, mothers

Wstęp

Zaburzenia $\mathrm{z}$ tzw. spektrum autyzmu (ang. autism spectrum disorders - ASD) aktualnie klasyfikuje się do zaburzeń neurorozwojowych. Zgodnie z najnowszą wersją podręcznika klasyfikacyjnego zaburzeń psychicznych opracowanego przez Amerykańskie Towa- 
rzystwo Psychiatryczne, tj. w DSM - $\mathrm{V}^{1}$ zaburzenia ze spektrum autyzmu charakteryzują się nieprawidłowościami w zakresie społecznego komunikowania się, w tym budowania relacji społecznych, którym towarzyszą sztywne/ograniczone wzorce zachowania, zainteresowań i aktywności.

Warto wspomnieć, że pomimo licznych eksploracji nad etiologią autyzmu, często z wykorzystaniem zaawansowanych technologicznie metod, w dalszym ciągu nie wiemy, jaka jest przyczyna tego zaburzenia. W patogenezie autyzmu najczęściej wskazuje się na podłoże wieloczynnikowe, genetyczno-środowiskowe, z podkreśleniem ważności interakcji pomiędzy układem nerwowym a immunologicznym².

Współczesna wiedza nie wyjaśnienia także rosnącej liczby rozpoznań zaburzeń ze spektrum autyzmu wśród dzieci. Autyzm, który niegdyś zaliczany był do grupy rzadkich zaburzeń, obecnie przypisywany jest do najczęstszych problemów rozwojowych u dzieci. $\mathrm{Z}$ badań przedstawionych przez Centers for Disease Control and Prevention ${ }^{3}$ wynika, że zaburzenia ze spektrum autyzmu są obecne u jednej na 68 osób. Wyniki badań ${ }^{4}$ pochodzących $z$ innych krajów także wskazują na wysoką i stale wzrastającą tendencję diagnozowania tych zaburzeń $u$ dzieci. Fakt ten sprawia, że $\mathrm{z}$ roku na rok coraz większa grupa osób tj. dzieci z diagnozą ASD oraz ich rodziny, wymaga profesjonalnego wsparcia.

${ }^{1}$ APA 2013. W Polsce w ramach diagnozy autyzmu wykorzystuje się kryteria zawarte w klasyfikacji ICD-10, opracowanej przez Światową Organizację Zdrowia WHO, 2002, jednakże najnowsza klasyfikacja APA warta jest szczególnej uwagi bowiem dobrze odzwierciedla współczesny stan wiedzy na temat autyzmu. Problematyka ta nie będzie jednak przedmiotem rozważań w tej pracy.

2 S.A. Currenti, Understanding and determining the etiology of autism, "Cellular and Molecural Neurobiology" 2010, vol. 30, s. 161-171; L. Dodds et. al., The role of prenatal, obstetric and neonatal factors in the development of autism, "Journal of Autism and Developmental Disorders" 2011, vol. 41, s. 891-902.

${ }^{3}$ Centers for Disease Control and Prevention Data\& Statistics na: http:/ / www. cdc.gov/ncbddd/autism/data.html [dostęp: 29.06.2014].

${ }^{4}$ C.M. Zaroff, S.Y. Uhm, Prevalence of autism spectrum disorders and influence of country of measuremnet and ethnicity. "Social Psychiatry and Psychiatric Epidemiology" 2012, 47(3), 395-398. 
W literaturze przedmiotu wiele miejsca poświęca się trudnościom rodziców związanym $\mathrm{z}$ wychowaniem i opieką nad dzieckiem z niepełnosprawnością. Szczególne zainteresowanie badaczy budzą jednak matki, które postrzegane są przez otoczenie społeczne jako główne opiekunki. W konsekwencji takiego oczekiwania społecznego nierzadko same matki postrzegają siebie jako nieocenione, niezastąpione $\mathrm{w}$ obowiązkach wynikających $\mathrm{z}$ opieki i rehabilitacji dziecka ${ }^{5}$. Realizacja roli matki - matki dziecka z niepełnosprawnością, staje się dla wielu z nich nadrzędnym kierunkiem samorealizacji.

Jak dowodzą liczne badania ${ }^{6}$ zaburzenie rozwoju dziecka znacząco wpływa na zdrowie fizyczne, dobrostan psychiczny matek oraz na ocenę jakości życia. Permanentne trudności towarzyszące matkom dzieci z zaburzeniami rozwoju mogą prowadzić do zmian w obrazie siebie. Taka sytuacja, jak pokazują badania ${ }^{7}$, sprzyja obniżeniu samooceny, zwłaszcza $\mathrm{w}$ zakresie poczucia kompetencji rodzicielskich, a także doświadczeniu niespełnienia w roli matki. Są

${ }^{5}$ M. Parchomiuk, Zasoby osobiste matek dzieci niepetnosprawnych. "CzłowiekNiepełnosprawność-Społeczeństwo" 2012, nr 1(15) s. 44-61.

${ }^{6} \mathrm{~A}$. Gretkowski, Pomoc psychologiczno-pedagogiczna rodzinie i dziecku przewlekle choremu, [w:] Pomoc dziecku i rodzinie w sytuacji kryzysowej, teoria, historia, praktyka, red. I. Kurlak, A. Gretkowski, Wydawnictwo Diecezjalne i Drukarnia w Sandomierzu, Stalowa Wola - Sandomierz 2008, s. 211-232; R. McConkey, M. Truesdale-Kennedy, The impast on mothers of bringing up a child with intellectual disabilities: a cross-cultural study, "International Journal of nursing Studiem” 2008, 45, s. 65-74; M. Feldman, L. McDonald, L. Serbin, D. Stack, M.L. Secco, C.T. Yu, Predictors of depressive symptoms in primary caregivers of young children with or at risk for developmental delay, "Journal of Intellectual Disability Research" 2007, 51, s. 606-619; E. Pisula, Samotność wśród najblizszych. Interakcje dzieci $z$ autyzmem $z$ rodzicami, "Czasopismo Psychologiczne" 2009, 15, s. 295-304; por. E. Zasępa, Poczucie koherencji rodziców dzieci z zaburzeniami rozwoju, [w:] Rodzina osób z niepetnosprawnościa intelektualna wobec wyzwań wspótczesności, red. Z. Żyta, Wydawnictwo Edukacyjne Akapit, Toruń 2010, s. 71-84.

7 P.R. Benson, The in past of child symptom severity on depressed mood among parents of children with ASD: The mediating role of stress proliferation, "Journal of Autism and Developmental Disorders" 2006, 36, s. 685-695; M. Parchomiuk, Rodzice dzieci $z$ mózgowym porażeniem dziecięcym wobec sytuacji trudnych: Wydawnictwo UMCS, Lublin 2007, s. 100; L.E. Tobing, D.S. Glenwick, Predictors and moderators of psychological distress in mothers of children with pervasive developmental disorders, "Journal of Family Social Work" 2006, 10, s. 1-22. 
jednak i takie opracowania empiryczne ${ }^{8}$, które dowodzą, że zdobyte przez matki doświadczenia wypływające ze sprawowania opieki nad dzieckiem z problemami w rozwoju mogą stać się źródłem poczucia własnej wartości, znaczenia oraz wzrostu samooceny.

Należy podkreślić, że rodzice sprawujący opiekę nad dzieckiem $\mathrm{z}$ niepełnosprawnością nie stanowią grupy homogenicznej w zakresie reprezentowanych cech, zachowań czy stanów ${ }^{9}$. W kontekście stresu rodzicielskiego zróżnicowanie to zależne jest od trzech zasadniczych zbiorów czynników, tj. czynników charakteryzujących dziecko (np. rodzaj, stopień jego niepełnosprawności, osobowość, temperament); czynników charakteryzujących rodzica (np. wiek, płeć, poziom wykształcenia oraz właściwości psychiczne) oraz czynników tzw. zewnętrznych, do których zalicza się m.in.: sposób przekazania diagnozy rodzicom, jakość kontaktu ze specjalistami, dostępność usług specjalistycznych oferowanych dla dziecka i ich samych, postawy otoczenia wobec niepełnosprawności dziecka, przynależność do organizacji społecznych/zrzeszeń, możliwość odpoczynku oraz sytuacja ekonomiczna rodziny.

Badania, w których analizowano wpływ rodzaju zaburzenia w rozwoju dziecka na stres rodzicielski, nie pozwalają jednoznacznie opowiedzieć się w kwestii związku między tymi zmiennymi. Niektóre prace wskazują na istnienie związku między rodzajem zaburzenia a poziomem oraz charakterem stresu. Jest on wyższy jak wskazują niektóre badania ${ }^{10}-\mathrm{u}$ matek dzieci $\mathrm{z}$ autyzmem niż

${ }^{8} \mathrm{~J}$. Barlow, L. Cullen-Powell, A. Cheshire, The effectiveness of the training and support program for parents of children with disabilities: a randomized controlled trial, "Journal of Psychosomatic Research" 2008, 64, s. 55-62; por. E.M. Dykens, Toward a positive psychology of mental retardation, "American Journal of Orthopsychiatry" 2006, 76, s. 185-193; R.M. Hodapp, T.M. Ly, D.J. Fidler, L.A. Ricci, Less stress, more rewaring: parenting children with Down syndrome, "Parenting: Science and Practice" 2001, 1, s. 317-337.

9 Por. M. Parchomiuk, Zasoby osobiste matek dzieci niepetnosprawnych, "Człowiek, niepełnosprawność, społeczeństwo" 2012, nr 1(15), s. 43-65.

10 P.R. Benson, op. cit.; E. Pisula, Psychologiczne problemy rodziców dzieci z zaburzeniami rozwoju, Wydawnictwo UW, Warszawa, 1998, s. 220; L.A. Schieve, S.J. Blumberg, C. Rice, S.N. Visser, C. Boyle, The relationship between autism and parental stress, "Pediatrics" 2007, 1, s. 114-121. 
u matek dzieci z zespołem Downa, a także matek dzieci z mózgowym porażeniem dziecięcym. Należy jednak podać, że istnieją eksploracje, których wyniki nie potwierdzają różnicy ${ }^{11}$. Przykładowo Susan E. Waisbren ${ }^{12}$ wykazała, że pod względem zdrowia fizycznego, aktywności społecznej, relacji w małżeństwie czy planów na przyszłość rodzice dzieci z niepełnosprawnością nie różnili się do rodziców sprawujących opiekę nad dzieckiem neurotypowym w tym samym wieku.

\section{Założenia i organizacja badań własnych}

Proces badawczy miał dostarczyć odpowiedzi na postawiony problem badawczy ujęty $w$ brzmieniu: jaki jest poziom doświadczanego stresu rodzicielskiego $\mathrm{u}$ matek dzieci $\mathrm{z}$ autyzmem (stanowiących grupę podstawową, GA) w stosunku do tego, jaki ujawniają matki dzieci z zespołem Downa (pierwsza grupa porównawcza, GD) oraz matki dzieci rozwijających się prawidłowo (będące drugą grupą porównawczą, GN).

Hipotetyczna odpowiedź udzielona na podstawie analizy dostępnych opracowań teoretycznych i empirycznych zakłada istnienie różnic w zakresie poziomu doświadczanego stresu rodzicielskiego między badanymi grupami matek, przy czym matki dzieci $\mathrm{z}$ autyzmem charakteryzować się będą najwyższym poziomem doświadczanego stresu.

W badaniu własnym wykorzystano następujące narzędzia: skróconą wersję - 11-czynnikową Kwestionariusza Zasobów i Stresu dla Rodzin z Przewlekle Chorymi lub Niepełnosprawnymi Członkami

11 W.S. Burnett, G.C. Boyce, Effects of children with Down syndrome on parents activitie, "American Journal on Mental Retardation" 1995, 100, s. 115-127; M. Krauss, Child-related and parenting stress:similarities and differences between mothers and fathers of children with disabilities, "American Journal on Mental Retardation" 1993, t. 97, nr 4, s. 359-363.

12 S.E. Waisbren, Parents reactions after the birth of a developmentally disabled child, “American Journal of Mental Deficiency" 1980, 84, s. 345-351. 
(QRS) Jean Holroyd w adaptacji Ewy Pisuli oraz kwestionariusze ankiety własnej konstrukcji.

Skala QRS tworzy jedenaście skal, które zostały zaliczone do trzech głównych obszarów. Mierzą one subiektywną ocenę obciążeń przez stresory związane $\mathrm{z}$ opieką nad dzieckiem oraz dostępność zasobów pomocnych $\mathrm{w}$ radzeniu sobie $\mathrm{z}$ nimi. Wyróżnione obszary to: problemy dziecka (zależność od opieki, zaburzenia i deficyty poznawcze ograniczenia w rozwoju fizycznym); problemy badanego (perspektywa konieczności ciągłej opieki nad dzieckiem, brak wzmocnień osobistych, stres związany z chorobą terminalną, preferowanie opieki instytucjonalnej, obciążenia osobiste); problemy rodzinne (ograniczenia możliwości rodziny, dysharmonia w rodzinie, problemy materialne).

Powyższe narzędzie spełnia warunki poprawności psychometrycznej (także polska wersja językowa wykazuje wysoką rzetelność: $r=0,70$ ) i było wielokrotnie wykorzystywane przez badaczy z uwzględnieniem różnych grup respondentów.

W celu ustalenia danych socjodemograficznych dla trzech badanych grup matek oraz informacji odnoszących się do niepełnosprawności dziecka (lub też jej braku), zastosowano ankiety własnej konstrukcji.

W badaniach wzięło udział 39 matek dzieci z autyzmem, 40 matek dzieci z zespołem Downa oraz 40 matek dzieci rozwijających się prawidłowo. Wszystkie dzieci badanych matek uczęszczały do szkół bądź ośrodków terapeutycznych.

Matki z grupy podstawowej dobrane zostały pod względem kilku kryteriów, tj.: diagnoza dziecka - autyzm dziecięcy, postawiona co najmniej trzy lata przed przeprowadzeniem badania; wiek dziecka - od 7 do 17 lat; brak współwystępowania z autyzmem innych zaburzeń (np. zespołu Downa, mózgowego porażenia dziecięcego, innych zdiagnozowanych zaburzeń). Natomiast grupy porównywane $\mathrm{z}$ grupą matek dzieci $\mathrm{z}$ autyzmem zostały dobrane na zasadach zmodyfikowanego doboru losowego.

Porównanie rozkładu charakterystyk demograficznych badanych matek przy użyciu testu nieparametrycznego Kołmogorowa-Smir- 
nowa wykazało, iż między grupami matek dzieci z autyzmem i dzieci z zespołem Downa nie było różnic w zakresie wieku, poziomu wykształcenia, środowiska zamieszkania, aktywności zawodowej oraz wieku dziecka. Podobnie nie stwierdzono różnic w zakresie zmiennych demograficznych w grupach porównawczych. Między grupami matek dzieci z autyzmem a matkami dzieci neurotypowymi wystąpiła różnica w zakresie wieku dziecka - więcej było dzieci w wieku 12-17 lat w grupie matek dzieci prawidłowo rozwijających się.

Średni wiek matek dzieci z autyzmem wynosił ok. 40 lat (średnia 39,54; odchylenie standardowe 7,54), matek dzieci z zespołem Downa 43 lata (średnia 42,9; odchylenie standardowe 7,65), a matek dzieci neurotypowych 37 lat (średnia 37,15; odchylenie standardowe $4,94)$. Najwięcej badanych matek posiadało wykształcenie wyższe (GA 29 osób, 39,2\%; GD 18 osób, 45\%; GN 22 osoby, 55\%) i pochodziło z dużego środowiska miejskiego - powyżej 100 tys. mieszkańców (GA 25 osób, 64,1\%; GD 22 osoby, 55\%; GN 28 osób, 70\%).

\section{Wyniki}

Ze względu na brak normalności rozkładu mierzonej zmiennej $\mathrm{w}$ poszczególnych grupach matek, $\mathrm{w}$ analizach zastosowano test nieparametryczny U Manna-Whitneya.

Analizie poddano wyniki jedenastu skal Kwestionariusza Zasobów i Stresu dla Rodzin z Przewlekle Chorymi lub Niepełnosprawnymi Członkami. Wyniki analiz przedstawia tabela 1.

Jak wynika z poniższej tabeli, w zakresie pięciu spośród jedenastu skal Kwestionariusza Zasobów i Stresu matki dzieci z autyzmem uzyskały wyniki istotnie wyższe niż matki dzieci z zespołem Downa. W porównaniu z wynikami matek dzieci rozwijających się prawidłowo, matki dzieci $\mathrm{z}$ autyzmem uzyskały istotnie wyższe wyniki poziomu stresu w siedmiu skalach. Poniżej przedstawiono szczegółowy opis wyników otrzymanych przez badane matki $\mathrm{w}$ grupach wyodrębnionych ze względu na rodzaj zaburzenia występującego u dziecka. 
م.

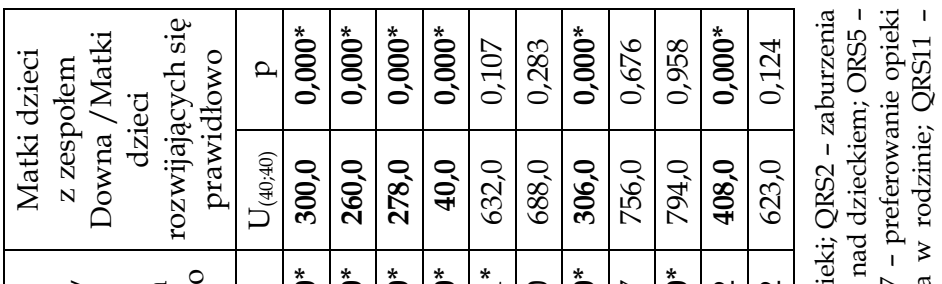

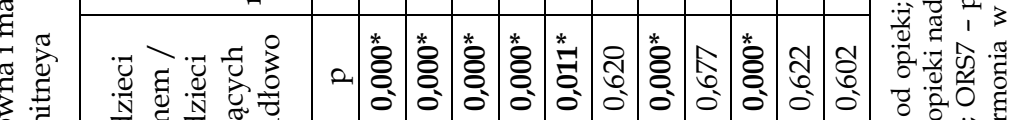
年

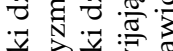

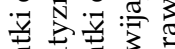
$\sum_{i}^{\pi} \sum_{N}^{\pi} \sum_{i=1}^{\pi}$

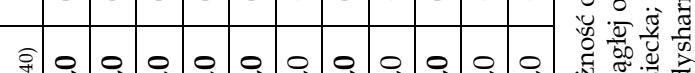

高

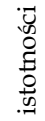

군

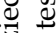

ते $\cdot \bar{\nabla}$

ㄴ.

㲾

ध

Eี

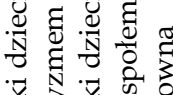

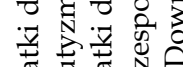
$\sum_{N}^{\pi} \sum_{N}^{\pi}$

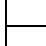

ก

స

․․

प्य

光 荧

घ

이뭄

क

ए

त्र

गु

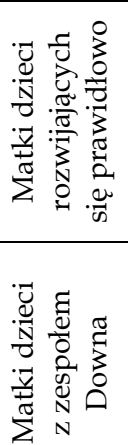

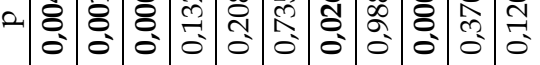

局.

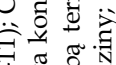

용

이일

包 尔

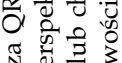

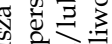

해

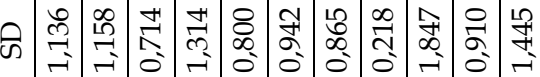

要

दे $N$ i

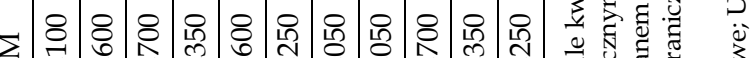

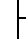

+

क

เi.

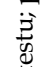

瓷

3 


\section{Obszar I - stres związany z problemami dziecka}

- Stres związany z zależnością dziecka od opieki (QRS 1)

W zakresie tym matki dzieci z zaburzeniami w rozwoju (tj. z autyzmem i z zespołem Downa) różniły się istotnie od matek dzieci rozwijających się prawidłowo. Postrzegały one swoje dzieci jako bardziej zależne od opieki. W zakresie omawianego wskaźnika stresu wystąpiły także różnice między matkami dzieci z autyzmem a matkami dzieci z zespołem Downa. Te pierwsze doświadczały większego stresu z powodu zależności od opieki niż matki dzieci $\mathrm{z}$ zespołem Downa.

- Stres związany z zaburzeniami i deficytami poznawczymi (QRS 2)

Matki dzieci z problemami rozwojowymi spostrzegały obciążenia związane z zaburzeniami i deficytami poznawczymi u dziecka jako większe niż matki dzieci rozwijających się prawidłowo. Pomiędzy matkami dzieci z autyzmem i matkami dzieci z zespołem Downa także wykazano istotne statystycznie różnice. U matek dzieci $\mathrm{z}$ autyzmem poziom stresu był w tym zakresie wyraźnie wyższy niż u matek dzieci z zespołem Downa.

- Stres związany z ograniczeniami w rozwoju fizycznym dziecka (QRS 3)

Ograniczenia w rozwoju fizycznym dziecka były oceniane jako większe przez matki dzieci dotkniętych zaburzeniami rozwoju w porównaniu z matkami dzieci rozwijających się prawidłowo. Okazało się również, że matki dzieci z autyzmem doświadczały większego stresu $\mathrm{z}$ powodu ograniczeń w rozwoju fizycznym dziecka niż matki dzieci z zespołem Downa.

\section{Obszar II - problemy badanego}

- Stres związany z perspektywą konieczności ciągłej opieki nad dzieckiem (QRS 4) 
Zarówno matki dzieci z autyzmem, jak i matki dzieci z zespołem Downa doświadczały w podobnym zakresie stresu związanego z perspektywą ciągłej opieki nad dzieckiem. Z kolei w stosunku do matek dzieci rozwijających się prawidłowo, zarówno u matek dzieci z zespołem Downa, jak i matek dzieci z autyzmem, poziom stresu był w tym zakresie wyraźnie wyższy.

- Stres związany z brakiem wzmocnień osobistych (QRS 5)

Brak wzmocnień osobistych był oceniony jako większy przez matki dzieci z autyzmem w porównaniu z matkami dzieci rozwijających się prawidłowo. $\mathrm{W}$ ocenie omawianego wskaźnika nie wystąpiły różnice między matkami dzieci z autyzmem a matkami dzieci z zespołem Downa oraz matkami dzieci z zespołem Downa w porównaniu z matkami dzieci rozwijającymi się prawidłowo.

- Stres związany ze stanem zdrowia i/lub chorobą terminalną dziecka (QRS 6)

Analiza poziomu stresu w grupach matek nie wykazała między badanymi grupami różnic istotnych statystycznie.

- Stres związany z preferowaniem opieki instytucjonalnej (QRS 7)

Matki dzieci z zaburzeniami w rozwoju (tj. $\mathrm{z}$ autyzmem i z zespołem Downa) doświadczały wyższego poziomu stresu niż matki dzieci rozwijających się prawidłowo. Między grupami matek dzieci z autyzmem i zespołem Downa także stwierdzono różnice. Matki dzieci z autyzmem doświadczały większego stresu związanego z preferowaniem opieki instytucjonalnej niż matki dzieci z zespołem Downa.

- Stres związany z obciążeniami osobistymi (QRS 8)

$\mathrm{W}$ ramach tej skali matki dzieci z autyzmem i z zespołem Downa nie różniły się od matek dzieci rozwijających się prawidłowo. Nie było też istotnych różnic między grupami matek dzieci z zaburzeniami rozwoju. 


\section{Obszar III - problemy rodziny}

- Stres związany z ograniczeniami możliwości rodziny (QRS 9)

Ograniczenia możliwości rodziny związane z opieką nad dzieckiem były ocenione jako większe przez matki dzieci z autyzmem w porównaniu z matkami dzieci z zespołem Downa i matkami dzieci rozwijających się prawidłowo. W zakresie tej skali nie wystąpiły różnice między matkami dzieci z zespołem Downa a matkami dzieci pełnosprawnych.

- Stres związany z dysharmonią w rodzinie (QRS 10)

W zakresie omawianego wskaźnika stresu nie wystąpiły różnice między matkami dzieci z autyzmem a matkami dzieci z zespołem Downa i matkami dzieci pełnosprawnych. Z kolei $\mathrm{u}$ matek dzieci rozwijających się prawidłowo poziom stresu był $w$ tym zakresie wyraźnie wyższy niż u matek dzieci z zespołem Downa.

- Stres związany z problemami materialnymi (QRS 11)

Analiza poziomu stresu w tym zakresie nie wykazała istotnych statystycznie różnic.

\section{Dyskusja}

W niniejszym badaniu zakładano, że matki dzieci z autyzmem charakteryzować się będą wyższym poziomem stresu niż matki dzieci z zespołem Downa i matki dzieci rozwijających się prawidłowo. Jak przypuszczano, najwięcej różnic zaobserwowano pomiędzy matkami dzieci z autyzmem a matkami dzieci funkcjonujących prawidłowo. Aż w siedmiu obszarach wyróżnionych w kwestionariuszu QRS matki dzieci z autyzmem uzyskały wyniki wyższe od matek dzieci rozwijających się prawidłowo. W zakresie pięciu podskal QRS wyniki matek dzieci z autyzmem były wyższe niż u matek dzieci z zespołem Downa. 
Matki dzieci z autyzmem w porównaniu z matkami dzieci pełnosprawnych oceniły swoje potomstwo jako bardziej zależne od opieki, a ich rozwój poznawczy oraz możliwości rozwoju fizycznego jako bardziej ograniczone. Doświadczały również silniejszego stresu związanego z perspektywą konieczności ciągłej opieki nad dzieckiem i z preferowaniem opieki instytucjonalnej. Także brak wzmocnień osobistych został oceniony jako większy przez matki dzieci z autyzmem niż przez matki dzieci rozwijających się prawidłowo. W porównaniu z matkami dzieci z zespołem Downa, matki dzieci z autyzmem doświadczały wyższego poziomu stresu związanego z zależnością od opieki, zaburzeniami i deficytami poznawczymi, ograniczeniami w rozwoju fizycznym oraz ograniczeniami możliwości rodziny. Ponadto matki dzieci z autyzmem, w stosunku do matek dzieci z zespołem Downa, doświadczały wyższego poziomu stresu związanego z preferowaniem opieki instytucjonalnej.

W oparciu o powyższe rezultaty można uznać, iż założona w pracy hipoteza została potwierdzona. Otrzymane wyniki w większości korespondują z wynikami wcześniejszych eksploracji13. $\mathrm{Na}$ komentarz zasługuje jednak kilka otrzymanych rezultatów.

Nieoczekiwany i relatywnie trudny do interpretacji rezultat wystąpił u badanych matek w zakresie stresu związanego z ograniczeniami w rozwoju fizycznym. Okazało się bowiem, że matki dzieci $\mathrm{z}$ autyzmem, w stosunku do matek dzieci z zespołem Downa, oceniły możliwości fizyczne swojego dziecka jako bardziej ograniczone. Teoretycznie rzecz ujmując, rozwój fizyczny - w tym rozwój ruchowy - dzieci z autyzmem mógłby wydawać się lepszy niż dzieci z zespołem Downa. Ze względu jednak na ograniczony kontakt $\mathrm{z}$ dzieckiem z autyzmem oraz jego trudności z komunikacją, zaburzenia w zakresie procesu ucznia się oraz opór wobec zmian, spra-

13 E. Pisula, Psychologiczne problemy rodziców..., s. 219; A. Dąbrowska, E. Pisula, Parenting stress and doping styles in mothers and fathers of pre-school children with autism and Down syndrome, "Journal of Intellectual Disability Research" 2010, 54, s. 266-280; G. Spratt, C.F. Sayler, M.M. Macias, Assessing parenting stress in multiple samples of children with special needs (CSN). Preview, "Families, Systems, Health" 2007, 25, s. $435-449$. 
wa jest bardziej złożona. Wiele dzieci z autyzmem osiąga dobrą sprawność fizyczną jedynie w pewnych zakresach ${ }^{14}$. Przykładowo dziecko może bardzo sprawnie i z dużą precyzją układać skomplikowane zestawy puzzli i jednoczenie mieć duże trudności $\mathrm{z}$ opanowaniem podstawowych czynności samoobsługowych, takich jak: samodzielne jedzenie, ubieranie się czy czynności związane z higieną. Anna Dąbrowska i Ewa Pisula ${ }^{15}$ także wykazały różnice między matkami dzieci z autyzmem a matkami dzieci z zespołem Downa, z tym że to matki dzieci z zespołem Downa doświadczały istotnie wyższego poziomu stresu związanego z ograniczeniami fizycznymi dziecka. Z dużą pewnością można założyć, że na różnice w wynikach tych badań mógł wpłynąć wiek dziecka. W przytaczanym badaniu udział brały matki młodszych dzieci (wiek dziecka mieścił się w granicach od 2. do 6. roku życia). W tym okresie życia w rozwoju motorycznym dziecka zachodzą duże zmiany. Ponadto dysharmonie motoryczne $w$ tym wieku u dziecka z autyzmem mogą być jeszcze mniej widoczne niż później. Od dziecka siedmioletniego i starszego (w niniejszym badaniu wiek dzieci badanych rodziców mieścił się w przedziale od 7 do 17 lat) oczekuje się dojrzałości szkolnej, m.in. samodzielności w zakresie codziennych czynności samoobsługowych. Gdy dziecko znajduje się w grupie rówieśników, wiele jest okazji do porównań jego sprawności i sprawności innych dzieci.

Uwagi wymaga także wynik wskazujący na brak różnic między badanymi grupami matek $\mathrm{w}$ zakresie stresu wynikającego $\mathrm{z}$ problemów materialnych. Można było oczekiwać, że ze względu na koszty związane $\mathrm{z}$ zapewnieniem dziecku profesjonalnej opieki medycznej i terapeutycznej oraz z uwagi na fakt, iż najczęściej tylko jeden rodzic pracuje zawodowo, sytuacja finansowa rodzin dzieci z zaburzeniami rozwoju będzie trudniejsza. Taki obraz powstaje

14 J.R. Brasic, J.G. Gianutsos, Neuromotor assessment and autistic disorder, "Autism" 2000, 4, s. 287-298; E. Pisula, Małe dziecko z autyzmem - diagnoza i terapia, Gdańskie Wydawnictwo Psychologiczne, Gdańsk 2005, s. 50.

15 A. Dąbrowska, E. Pisula, op. cit. 
w świetle wielu wyników badań ${ }^{16}$. W niniejszym badaniu okazało się jednak, że standard życia rodzin wychowujących dzieci z zaburzeniami rozwoju, pomimo wszelkich utrudnień i nakładów ponoszonych na leczenie i rehabilitację, był taki sam jak w przypadku rodzin dzieci rozwijających się prawidłowo. Być może obecna sytuacja społeczno-ekonomiczna kraju, skutki przemian potransformacyjnych (masowe zwolnienia pracowników, zamykanie nierentownych zakładów pracy, niewydolność kredytowa wielu rodzin itp.) dotykają w porównywalnym stopniu obu grup rodzin. Podobny wynik uzyskała Elżbieta Minczakiewicz ${ }^{17}$ w odniesieniu do rodziców dzieci z zespołem Downa i rodziców dzieci rozwijających się prawidłowo. Nie należy jednak zapominać, że badana grupa nie jest reprezentatywna dla ogółu rodzin z dziećmi z autyzmem w Polsce i nie należy wniosków płynących z tego badania nadmiernie uogólniać.

Podsumowując, analiza uzyskanych danych wskazała na te sfery funkcjonowania dziecka, rodzica i środowiska, które wiążą się z największymi obciążeniami doświadczanymi przez rodziców dzieci z autyzmem. Informacje te wydają się mieć duże znaczenie praktyczne. Znajomość źródeł stresu rodzicielskiego u osób udzielających pomocy rodzinom dzieci z zaburzeniami w rozwoju może przyczynić się do zaplanowania bardziej adekwatnego i pożądanego wsparcia. Ponadto wiedza na temat charakterystycznych cech i zachowań dziecka warunkujących podwyższenie poziomu stresu u rodziców wpłynąć może na zaplanowanie interwencji w taki sposób, by stres ten zminimalizować.

Przedstawiona powyżej analiza wyników wskazała także obszary, w których nie stwierdzono istotnych różnic między badanymi

16 A. Firkowska-Mankiewicz, Jakość życia rodzin z dzieckiem niepetnosprawnym, „Psychologia Wychowawcza” 1999, 2, s. 134-145; por. M. Parchomiuk, op. cit., s. 36.

17 E. Minczakiewicz, Sytuacja rodzin z dzieckiem z zespołem Downa na tle sytuacji wspótczesnych polskich rodzin statystycznych, w: Rodzina osób z niepetnosprawnościa intelektualną wobec wyzwań wspótczesności, red. Z. Żyta, Wydawnictwo Edukacyjne Akapit, Toruń 2010, s. 41-55. 
grupami matek. Obszary te stanowić mogą źródła zasobów sprzyjających radzeniu sobie. Najniższy poziom stresu $u$ matek dzieci z autyzmem wystąpił w zakresie skali QRS 10, tj. stresu związanego z dysharmonią w rodzinie, skali QRS 8 - obciążeniami osobistymi, skali QRS 11 - problemami materialnymi oraz skali QRS 6 - stresu związanego ze stanem zdrowia dziecka. Jak można przypuszczać, niskie wyniki uzyskane przez matki w zakresie stresu związanego z obciążeniami osobistymi związane są z relatywnie dobrą sytuacją finansową rodziny, a co za tym idzie, także z możliwością korzystania z pomocy osób spoza rodziny.

Rezultat dotyczący stresu związanego z dysharmonią w rodzinie może wspierać pogląd mówiący, iż fakt niepełnosprawności dziecka nie musi wpływać na spójność, integrację czy też więź między członkami ${ }^{18}$. Wprawdzie niewykluczone jest, że w wielu przypadkach zaburzenie rozwoju dziecka może sprzyjać ujawnieniu się negatywnych emocji czy nasileniu pewnych problemów w rodzinie, to jednak zaburzenie rozwoju dziecka nie stanowi przypuszczalnie ich pierwotnej przyczyny. Należy dodać, że nie wszyscy badacze odnotowali jednak brak dysharmonii w rodzinie dziecka $\mathrm{z}$ autyzmem. Przytaczane już wcześniej badanie A. Dąbrowskiej i E. Pisuli wykazało, znacznie wyższy poziom stresu w tym zakresie u matek dzieci z autyzmem niż $\mathrm{u}$ matek dzieci z zespołem Downa. Nie jest wykluczone, że poziom stresu w tym obszarze jest zróżnicowany w zależności od wieku dziecka, a zatem także czasu trwania związku rodziców.

Problematyka stresu u rodziców dzieci z autyzmem była przedmiotem wielu opracowań naukowych, jednocześnie wielość zależności w tym obszarze nie doczekało się ostatecznych rozstrzygnięć. Czasy transformacji i postępująca globalizacja zmuszają do uwzględnienia kolejnych determinantów $\mathrm{w}$ analizach trudności wynikających z nieradzenia sobie przez rodziców dzieci z zaburzeniami rozwoju. Zmienne warte eksploracji to na pewno: świadomość

18 A. Żmijewska, Zespót Aspergera w ujęciu rodzinnym - przegląd badań, „Psychiatria Polska" 2010, 44, s. 713-722. 
i aktywność rodziców w domaganiu się praw należnych dziecku, umiejętności korzystania $\mathrm{z}$ najnowszych technologii komputerowych. Rozstrzygnięcia empiryczne w temacie stresu rodzicielskiego powinny być stale poddawane weryfikacji ${ }^{19}$.

Na koniec warto wspomnieć o pewnych ograniczeniach badania zaprezentowanego w tej pracy, które nakazują ostrożność przy interpretacji wyników. Pierwszym z nich jest wielkość badanych grup oraz ich niereprezentatywny charakter. Także fakt, że badania zostały przeprowadzone $\mathrm{w}$ jednym rejonie Polski (województwo śląskie, powiat częstochowski) nie pozwala na duże uogólnianie wniosków płynących z tego badania. Inne ograniczenie wynika z faktu, że badanie nie miało charakteru podłużnego. Szczególnie wartościowe w odniesieniu do analizowanej problematyki byłyby badania longitudinalne, oraz badania włączające w analizy zmienną - status funkcjonalny dziecka. Badania ${ }^{20}$ udowodniły bowiem, że zmienna ta trafniej niż typologia niepełnosprawności, nakreśla istotę obciążeń rodzicielskich i ma znaczenie na kształtowanie się wyników stresu rodzicielskiego.

\section{Bibliografia}

Barlow J., Cullen-Powell L., Cheshire A., The effectiveness of the training and support program for parents of children with disabilities: a randomized controlled trial, "Journal of Psychosomatic Research" 2008, 64.

Benson P.R., The in past of child symptom severity on depressed mood among parents of children with ASD: The mediating role of stress proliferation, "Journal of Autism and Developmental Disorders" 2006, 36.

Brasic J.R., Gianutsos J.G., Neuromotor assessment and autistic disorder, "Autism" 2000, 4.

Burnett W.S., Boyce G.C., Effects of children with Down syndrome on parents activitie, “American Journal on Mental Retardation" 1995, 100.

19 A. Krause, Dziecko niepetnosprawne w rodzinie w perspektywie zmiany społecznej, [w:] Rodzina osób z niepetnosprawnościa intelektualna wobec wyzwań wspótczesności, red. Z. Żyta, Wydawnictwo Edukacyjne Akapit, Toruń 2010, s. 15-25.

${ }^{20}$ Por. M. Parchomiuk, op. cit., s. 36. 
Centers for Disease Control and Prevention. Data\& Statistics na: http://www.cdc. gov/ncbddd/autism/data.html [dostęp: 29.06.2014].

Currenti A., Understanding and determining the etiology of autism, "Cellular and Molecural Neurobiology" 2010, vol. 30.

Dąbrowska A., Pisula E., Parenting stress and doping styles in mothers and fathers of preschool children with autism and Down syndrome, "Journal of Intellectual Disability Research" 2010, 54.

Dodds L. et.al., The role of prenatal, obstetric and neonatal factors in the development of autism, "Journal of Autism and Developmental Disorders" 2011, vol. 41.

Dykens E.M., Toward a positive psychology of mental retardation, "American Journal of Orthopsychiatry" 2006, 76.

Feldman M., McDonald L., Serbin L., Stack D., Secco M.L, Yu, C.T., Predictors of depressive symptoms in primary caregivers of young children with or at risk for developmental delay, "Journal of Intellectual Disability Research” 2007, 51.

Firkowska-Mankiewicz A., Jakość życia rodzin z dzieckiem niepetnosprawnym, „Psychologia Wychowawcza" 1999, 2.

Gretkowski A., Pomoc psychologiczno-pedagogiczna rodzinie $i$ dziecku przewlekle choremu, [w:] Pomoc dziecku i rodzinie w sytuacji kryzysowej, teoria, historia, praktyka, red. I. Kurlak, A. Gretkowski, Wydawnictwo Diecezjalne i Drukarnia w Sandomierzu, Stalowa Wola - Sandomierz 2008.

Hodapp R.M., Ly T.M., Fidler D.J., Ricci L.A., Less stress, more rewarding: parenting children with Down syndrome, "Parenting: Science and Practice" 2001, 1.

Krause A., Dziecko niepetnosprawne w rodzinie w perspektywie zmiany społecznej, [w:] Rodzina osób z niepetnosprawnościa intelektualna wobec wyzwań wspótczesności, red. Z. Żyta, Wydawnictwo Edukacyjne Akapit, Torun 2010.

Krauss M., Child-related and parenting stress:similarities and differences between mothers and fathers of children with disabilities, "American Journal on Mental Retardation" 1993, t. 97, nr 4.

McConkey R., Truesdale-Kennedy M., The impast on mothers of bringing up a child with intellectual disabilities: a cross-cultural study, "International Journal of nursing Studiem" 2008, 45.

Minczakiewicz E., Sytuacja rodzin z dzieckiem z zespołem Downa na tle sytuacji wspótczesnych polskich rodzin statystycznych, [w:] Rodzina osób z niepetnosprawnościa intelektualna wobec wyzwań wspótczesności, red. Z. Żyta, Wydawnictwo Edukacyjne Akapit, Torun 2010.

Parchomiuk M., Rodzice dzieci z mózgowym porażeniem dziecięcym wobec sytuacji trudnych: Wydawnictwo UMCS, Lublin 2007.

Parchomiuk M., Zasoby osobiste matek dzieci niepetnosprawnych. „Człowiek - Niepełnosprawność - Społeczeństwo" 2012, nr 1(15).

Pisula E., Małe dziecko z autyzmem - diagnoza i terapia, Gdańskie Wydawnictwo Psychologiczne, Gdańsk 2005. 
Pisula E., Psychologiczne problemy rodziców dzieci z zaburzeniami rozwoju, Wydawnictwo UW, Warszawa 1998.

Pisula E., Samotność wśród najbliższych. Interakcje dzieci z autyzmem z rodzicami, „Czasopismo Psychologiczne" 2009, 15.

Schieve L.A., Blumberg S.J., Rice C., Visser S.N., Boyle C., The relationship between autism and parental stress, "Pediatrics" 2007,1.

Spratt G., Sayler C.F., Macias M.M., Assessing parenting stress in multiple samples of children with special needs (CSN). Preview, "Families, Systems, Health" 2007, 25.

Tobing L.E., Glenwick D.S., Predictors and moderators of psychological distress in mothers of children with pervasive developmental disorders, "Journal of Family Social Work" 2006, 10.

Waisbren S.E., Parents reactions after the birth of a developmentally disabled child, "American Journal of Mental Deficiency" 1980, 84.

Zaroff C.M., Uhm S.Y., Prevalence of autism spectrum disorders and influence of country of measuremnet and ethnicity. "Social Psychiatry and Psychiatric Epidemiology" 2012, 47(3).

Zasępa E., Poczucie koherencji rodziców dzieci z zaburzeniami rozwoju, [w:] Rodzina osób z niepetnosprawnościa intelektualną wobec wyzwań wspótczesności, red. Z. Żyta, Wydawnictwo Edukacyjne Akapit, Torun 2010.

Żmijewska A., Zespót Aspergera w ujęciu rodzinnym - przegląd badań, „Psychiatria Polska" 2010, 44. 